\title{
Measuring the Vertical Profiles of Aerosol Extinction in the Lower Troposphere by MAX-DOAS at a Rural Site in the North China Plain
}

\author{
Siyang Cheng ${ }^{1, *}$, Junli Jin ${ }^{2, *}$, Jianzhong Ma ${ }^{1}$, Xiaobin Xu ${ }^{1} \oplus$, Liang Ran ${ }^{3}$, Zhiqiang Ma ${ }^{4}$, \\ Junming Chen ${ }^{1}$, Junrang Guo ${ }^{1}$, Peng Yang ${ }^{5}$, Yang Wang ${ }^{6}$ and Thomas Wagner ${ }^{6} \mathbb{B}$ \\ 1 State Key Laboratory of Severe Weather \& CMA Key Laboratory of Atmospheric Chemistry, \\ Chinese Academy of Meteorological Sciences, Beijing 100081, China; majz@cma.gov.cn (J.M.); \\ 13311298991@189.cn (X.X.); chenjm@cma.gov.cn (J.C.); guo7116@cma.gov.cn (J.G.) \\ 2 CMA Meteorological Observation Centre, Beijing 100081, China \\ 3 Key Laboratory of Middle Atmosphere and Global Environment Observation, Institute of Atmospheric \\ Physics, Chinese Academy of Sciences, Beijing 100029, China; shirleyrl@mail.iap.ac.cn \\ 4 Institute of Urban Meteorology, China Meteorological Administration, Beijing 100089, China; zqma@ium.cn \\ 5 Meteorological Bureau of Shijiazhuang, Shijiazhuang 050081, China; yangpeng@suilongkeji.com \\ 6 Max Planck Institute for Chemistry, D-55020 Mainz, Germany; y.wang@mpic.de (Y.W.); \\ thomas.wagner@mpic.de (T.W.) \\ * Correspondence: sycheng@cma.gov.cn (S.C.); jinjl@cma.gov.cn (J.J.)
}

Received: 20 August 2020; Accepted: 25 September 2020; Published: 27 September 2020

\begin{abstract}
Ground-based multi-axis differential optical absorption spectroscopy (MAX-DOAS) measurements were performed during the summer (13 June-20 August) of 2014 at a rural site in North China Plain. The vertical profiles of aerosol extinction (AE) in the lower troposphere were retrieved to analyze the temporal variations of $\mathrm{AE}$ profiles, near-surface $\mathrm{AE}$, and aerosol optical depth (AOD). The average AOD and near-surface AE over the period of study were $0.51 \pm 0.26$ and $0.33 \pm 0.18 \mathrm{~km}^{-1}$ during the effective observation period, respectively. High AE events and elevated AE layers were identified based on the time series of hourly AE profiles, near-surface AEs and AODs. It is found that in addition to the planetary boundary layer height (PBLH) and relative humidity $(\mathrm{RH})$, the variations in the wind field have large impacts on the near-surface $\mathrm{AE}, \mathrm{AOD}$, and AE profile. Among 16 wind sectors, higher AOD or AE occur mostly in the directions of the cities upstream. The diurnal variations of the AE profiles, AODs and near-surface AEs are significant and influenced mainly by the source emissions, PBLH, and RH. The AE profile shape from MAX-DOAS measurement is generally in agreement with that from light detection and ranging (lidar) observations, although the AE absolute levels are different. Overall, ground-based MAX-DOAS can serve as a supplement to measure the $\mathrm{AE}$ vertical profiles in the lower troposphere.
\end{abstract}

Keywords: aerosol extinction; vertical profile; ground-based MAX-DOAS; lidar; North China plain

\section{Introduction}

Along with the rapid development of economy and society, aerosol loading levels across China sharply increased over the past several decades [1]. Although the concentrations of particulate matter in aerodynamic diameter less than or equal to $2.5 \mu \mathrm{m}\left(\mathrm{PM}_{2.5}\right)$ have continued to decrease in most cities since 2013, events of haze associated with high aerosol extinction (AE) still occur frequently, especially in the North China Plain (NCP) during the winter [2]. Aerosol particles not only greatly affect the air quality, but also have direct effects on radiative forcing and indirect effects on clouds [3,4]. Therefore, 
aerosols play an important role in the radiation budget of the Earth-atmosphere system and global climate change, and then affect the weather, climate, and human health $[4,5]$.

Aerosol optical properties include aerosol extinction coefficient, aerosol optical depth (AOD, integrated AE in a vertical column), aerosol single scattering albedo (SSA), Ångström exponent, and aerosol scattering phase function. Owing to the lack of knowledge of these parameters, such as vertical distribution, the radiative forcing of aerosol in eastern Asia is still the subject of large uncertainties [6]. Aerosol extinction (scattering and absorption) is affected by many factors, such as the concentration level, chemical composition, size distribution, hygroscopic potential of aerosol particles and meteorological conditions (wind, relative humidity, and planetary boundary layer) ([7], and references therein). The well-known sun-photometer networks, such as the Aerosol Robotic Network (AERONET), Photométrie pour le Traitement Opérationnel de Normalisation Satellitaire (PHOTONS), China Aerosol Remote Sensing Network (CARSNET), and the sky radiometer network (SKYNET), have been used to investigate the spatio-temporal variation of AODs and for the validations of satellite retrieval and model simulation [8-10]. Meanwhile, satellite remote sensing has been widely used to monitor AODs with large spatio-temporal coverage. However, satellite AOD retrievals are highly influenced by the aerosol vertical profile assumption and aerosol optical properties [11]. So far, numerous studies have focused on the aerosol optical properties in the NCP [12-17], one of the most severe air pollution regions in China. For example, surface in situ measurements of aerosol scattering coefficient were carried out in summer at Raoyang, a rural site located in the southern part of the NCP $[18,19]$. The column or surface aerosol optical properties are not sufficient to understand the climate effect and environment influence of aerosols [20].

The vertical distribution and temporal evolution of aerosol optical properties are vital to reduce the uncertainty of evaluating aerosol radiative forcing [20]. Aerosol optical properties at different altitudes in the NCP were derived through in situ measurement using high tower, balloon, unmanned aerial vehicle, and aircraft as well as by the observation of remote sensing. For example, aerosol optical properties were measured by a turbo aircraft in the wintertime over Beijing, presenting a higher Ångström exponent, a smaller asymmetry factor, and relatively uniform vertical structures during the clean periods compared to the heavy pollution periods [21]. Recent flight observations showed that elevated layers of particle extinction could occur in summer over the rural area in the NCP [22]. The AOD enhancement due to water uptake could reach as high as $4.4 \pm 1.3$ under high relative humidity, and the enhancement in AE mostly occurred at the top of the planetary boundary layer [23]. Lidar, as a common remote-sensing instrument, is usually used to measure the AE profiles, but there is inevitably a blind zone close to the surface $[24,25]$. Real-time online measurements on the platforms of towers indicated that the vertical distributions of AE are complex below $300 \mathrm{~m}$ in winter, with different types closely related to the changes in the temperature inversion, mixing layer height, and source emissions [26,27]. New instruments and methods, such as camera-laser aerosol detective system, have been developed to monitor the AE profile during the heavy pollution period in the NCP [28]. However, related measurements above are insufficient to observe profiles of aerosol optical properties in the troposphere with no blind region and high time resolution.

Multi-axis differential optical absorption spectroscopy (MAX-DOAS) has the advantages of having relatively high time resolution, simple instrument structure, and automatic operation, and is suitable for short-term observations of aerosol optical properties [29-37]. For example, a new method, deducing aerosol scattering and absorption properties, has recently been developed based on the oxygen dimer $\left(\mathrm{O}_{4}\right)$ absorptions [38]. The MAX-DOAS technique, as a widely used technique and an additional option, can bridge the observation gap of $\mathrm{AE}$ vertical profile in the lower troposphere left by aircraft or light-detection and ranging (lidar) [39-44]. However, there have been relatively few studies on the characteristics of AE profiles retrieved by MAX-DOAS, especially in comparison with independent observations, such as the lidar AE profile [37,45-48]. AE profiles retrieved from MAX-DOAS measurements in northern NCP showed that most of aerosols were confined below $1 \mathrm{~km}$ with an exponential decay with height, and sometimes the AE peak in the profile appeared at 
$300 \mathrm{~m}$ altitude [49]. Recent MAX-DOAS observations in the central western NCP showed that high AEs are mainly located below $1.4 \mathrm{~km}$ altitude with frequent lifted layers, and induced by complex factors, such as regional transport [50]. However, the knowledge of AE profile in the NCP is still incomplete, and the comparisons of AE profile between MAX-DOAS inversion and other measurement are also sparse.

We made MAX-DOAS measurements during the field campaign of the Vertical Observations of trace Gases and Aerosols (VOGA) at Raoyang, a rural site of NCP, in summer 2014. The primary objective of this study is to retrieve the AE profiles from the MAX-DOAS measurement data, investigate the characteristics and temporal evolution of the AE vertical distribution over this polluted rural area, and compare MAX-DOAS results with lidar AE profiles. Section 2 describes the observational site, MAX-DOAS, and lidar instruments, process of spectral analysis, and the retrieval of AE vertical profiles. The time series and diurnal variation of AE vertical profiles as well as a comparison with lidar are shown in Section 3. The summary and conclusions are given in Section 4.

\section{Experiments}

\subsection{Site and Instrument}

The MAX-DOAS system was set up at the Raoyang meteorological station $\left(115^{\circ} 44^{\prime} \mathrm{E}, 38^{\circ} 14^{\prime} \mathrm{N}\right.$; $20 \mathrm{~m}$ above sea level), a rural site in the NCP (Figure 1a). This station is located in an agriculture county in the middle of Heibei Province, China. There are no large local industrial sources. However, it is surrounded by a cluster of industrial and populated cites, such as Hengshui, Shijiazhuang, Baoding, Cangzhou, Tianjin and Beijing at distances from 50 to $200 \mathrm{~km}$ [18,22,51,52]. MODIS satellite observations (here we use the MYD04_3K product) show that the AODs are higher in major neighborhood cities than at the observatory (Figure 1b).

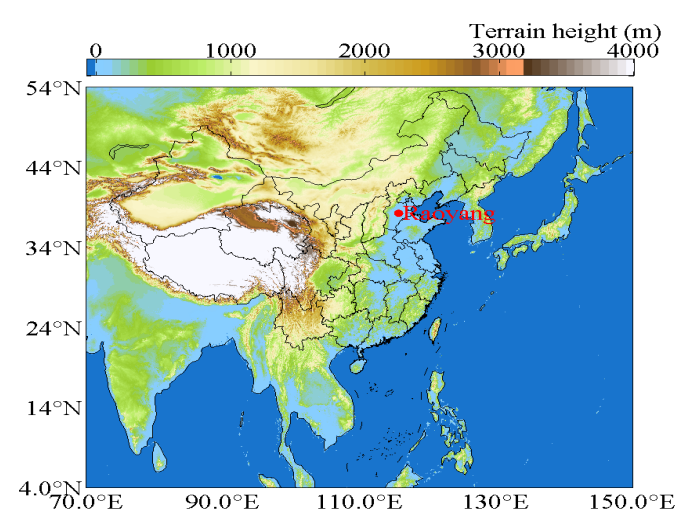

(a)

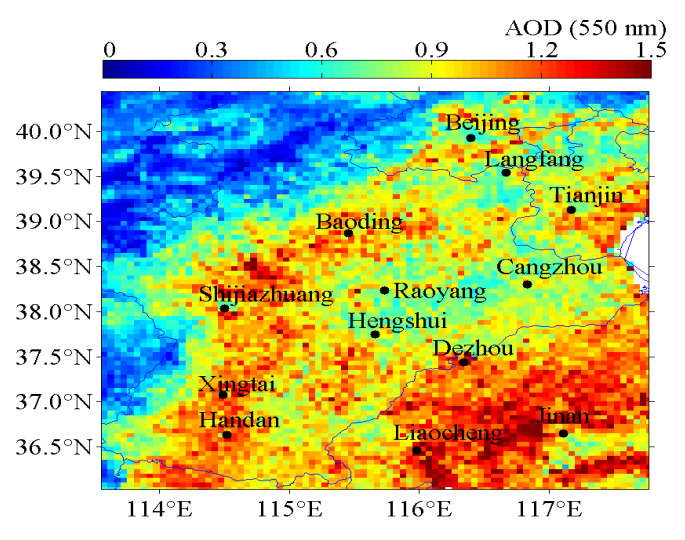

(b)

Figure 1. (a) Geographical location of the Raoyang Meteorological Station in the North China Plain (NCP); (b) average aerosol optical depths (AODs) in the summer (1 June-31 August) of 2014 extracted from the MYD04_3K product (Level 2, spatial resolution: $3 \mathrm{~km}$, temporal resolution: $5 \mathrm{~min}$ ) of the Moderate Resolution Imaging Spectroradiometer (MODIS) satellite. The observatory and its major neighborhood cities are marked by black dots.

Ground-based MAX-DOAS observations were conducted from 13 June to 20 August 2014 at Raoyang. The Mini MAX-DOAS instrument is a compact and relatively small instrument made by the Hoffmann Messtechnik GmbH in Germany and it contains the entrance optics, stepper motor, temperature controller, spectrograph, operational controller and data collector. The instrument was automatically run, recording the spectra of scattered sunlight at 11 elevation angles $\left(1-6^{\circ}, 8^{\circ}, 10^{\circ}, 15^{\circ}\right.$, $30^{\circ}$ and $90^{\circ}$ ). The telescope pointed approximately towards the southeast. The exposure time of each individual spectrum was $\sim 0.5 \mathrm{~min}$. The spectrograph covered the wavelength range of $292-447 \mathrm{~nm}$, 
operating at a stable temperature of $5{ }^{\circ} \mathrm{C}$. The spectra of dark current and electronic offset were also collected for correcting the measured spectra. A laptop with professional software was used to control the observation procedure. More descriptions about the same type of instrument are available in previous works [53-58].

\subsection{Spectral Analysis}

Based on the Beer-Lambert law, the $\mathrm{O}_{4}$ differential slant column densities (dSCDs) were retrieved from the measured spectra through the DOAS method [59]. The $\mathrm{O}_{4} \mathrm{dSCDs}$ represent the differences of $\mathrm{O}_{4}$ absorption between measurement spectra and the reference spectra. Two zenith spectra, measured before and after an off-zenith sequence of elevation angles, were interpolated and used as the reference spectrum. In this case, the $\mathrm{O}_{4} \mathrm{dSCDs}$ from spectral fitting can be approximately regarded as tropospheric $\mathrm{O}_{4}$ dSCDs, usually referred to as $\mathrm{O}_{4}$ delta slant column densities (delta SCDs) [29]. The spectral analysis was implemented using the QDOAS software (http://uv-vis.aeronomie.be/software/QDOAS/), based on the non-linear least squares fitting algorithm. For each measured spectrum a wavelength calibration is performed before spectral fitting. The setting of DOAS retrieval parameters can be referred to previous studies [50]. The $\mathrm{O}_{4} \mathrm{dSCDs}$ were retrieved by the configured parameters, involving the fitting window $(338-370 \mathrm{~nm})$, the cross sections of nitrogen dioxide $\left(\mathrm{NO}_{2}, 294 \mathrm{~K}, 220 \mathrm{~K}\right)$, ozone $\left(\mathrm{O}_{3}, 223 \mathrm{~K}, 243 \mathrm{~K}\right), \mathrm{O}_{4}(293 \mathrm{~K})$, formaldehyde $(\mathrm{HCHO}, 298 \mathrm{~K})$, bromine oxide $(\mathrm{BrO}, 228 \mathrm{~K})$, water $\left(\mathrm{H}_{2} \mathrm{O}\right.$, 293K), nitrous acid (HONO, 296K) and two Ring spectra, as well as polynomial degree (5 order) and intensity offset (polynomial of order 1). In the process of data quality control, we rejected the $\mathrm{O}_{4} \mathrm{dSCDs}$ when the root mean square (RMS) of spectral fitting residual was bigger than 0.003 , based on previous studies [50]. Figure 2 shows an example of DOAS fitting of $\mathrm{O}_{4}$, indicating that the $\mathrm{O}_{4}$ absorption structure can be extracted from measured spectra and fitted well.

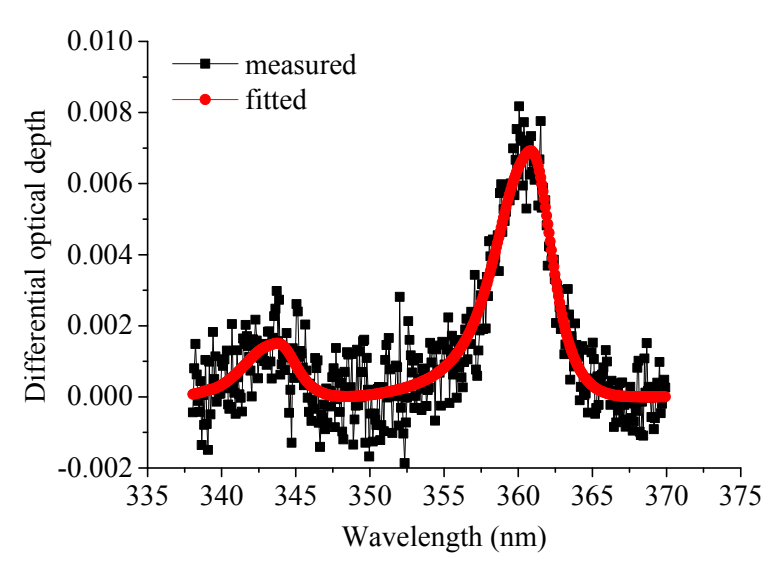

Figure 2. Example of spectral fitting for $\mathrm{O}_{4}$ corresponding to the elevation angle of $10^{\circ}$ at $11: 56$ LT (local time, UTC +8 h) on 13 June 2014. The black and red symbol-lines indicate the derived absorption structures from the measured spectra and the fitted absorption cross section, respectively. The fitted $\mathrm{O}_{4}$ differential slant column density (dSCD) is $1.65 \times 10^{43} \mathrm{molec}^{2} \cdot \mathrm{cm}^{-5}$, and the root mean square (RMS) of fitting residual between measured and fitted spectrum is $7.63 \times 10^{-4}$.

\subsection{Retrieval of the Vertical Profiles of Aerosol Extinction}

For each elevation sequence ( 12 min), a vertical profile of aerosol extinction at $360 \mathrm{~nm}$ in the troposphere is retrieved from $\mathrm{O}_{4}$ delta SCDs by the optimal estimation (OE) algorithm of the "Profile inversion algorithm of aerosol extinction and trace gas concentration developed by the Anhui Institute of Optics and Fine Mechanics, Chinese Academy of Sciences (AIOFM, CAS), in cooperation with the Max Planck Institute for Chemistry (MPIC)" (PriAM) [60]. Then the aerosol extinction in the 0-50 m layer adjacent to the surface, hereafter called near-surface $\mathrm{AE}$, can be extracted from the vertical profiles, and the AODs can be obtained by vertical integration. The parameters of surface albedo, single scattering 
albedo of aerosol particles, and asymmetry factor of scattering on aerosol particles were set as $0.06,0.95$, and 0.60 , respectively, referring to previous measurements at the same or nearby stations $[18,22,50,52]$. Temperature and pressure profiles were averaged from the ECMWF Reanalysis-Interim (ERA-Interim) product (https://www.ecmwf.int/en/forecasts/datasets/reanalysis-datasets/era-interim) at 0:00, 6:00, and 12:00 UTC for the summer (June, July, and August) of 2014. A smoothed box-shaped a priori AE profile was used in this study, the same as that used in a previous study [50]. The diagonal elements of the a-priori covariance matrix were set as 0.25 and didn't decrease with the altitudes in order to balance the flexibility and stability of the profile inversion. For the post-processing, we retained the data with the cost function of profile inversion smaller than 30 and the relative deviations of PriAM modelled and MAX-DOAS measured $\mathrm{O}_{4}$ dSCDs less than $30 \%$. The selected thresholds are based on the balance of data quality and amount. Under the condition of the selected thresholds, $71.41 \%$ AE profiles are retained and the average of OE cost function is 8.83 . In addition, we have tried to identify and classify the sky condition through MAX-DOAS observation [61,62]. However, the amount of MAX-DOAS data under clear sky condition is very limited (14.14\% among the qualified profile data) and the uncertainties of sky condition classification are hard to evaluate. Therefore, we use all the qualified MAX-DOAS data below without the classification of sky condition. Meanwhile, the aforementioned data quality process may partly reduce the influence of different sky conditions. Finally, 342 hourly AE profiles can be used for this research.

\subsection{Light Detection and Ranging (Lidar) Observation}

As part of the field campaign, the vertical profiles of aerosol extinction were also observed by the Leosphere lidar [22]. Based on the interaction of light with matter, a laser pulse at $355 \mathrm{~nm}$ was sent into the atmosphere, scattered back to the optical collection system, converted into an electronic signal and recorded by a computer. The full overlap between the outgoing beam and the field of view of the telescope was around $200 \mathrm{~m}$. The optical parameters of atmospheric particles at $355 \mathrm{~nm}$, such as extinction coefficients profiles, were retrieved from the lidar measurement using a default lidar ratio of $35 \mathrm{sr}$. The assumed constant lidar ratio may cause $20 \%$ uncertainties of the retrieved aerosol extinction $[39,40,63]$. The vertical and temporal resolutions of aerosol particle extinction profile were set as $15 \mathrm{~m}$ and $1 \mathrm{~min}$, respectively. We calculated the signal-to-noise ratio for each vertical profile of original signal (SNR), and discarded the outliers in the aerosol extinction profile once SNR was less than 20. The selected SNR threshold can discard the outliers at the high altitude and retain the data in the planetary boundary layer as many as possible. The qualified profiles were compared with MAX-DOAS results in the following section. More details of software and hardware about lidar can be found in the user manual of aerosol lidar ALS300 and ALS450 [22,63].

\section{Results and Discussion}

\subsection{Time Series of the Vertical Distribution of Aerosol Extinction}

Based on the aforementioned methods of spectral analysis and profile inversion, the AE profiles up to $4 \mathrm{~km}$ altitude with a vertical grid of $200 \mathrm{~m}$ were derived from MAX-DOAS observations. Due to no substantial information for the AE above $2 \mathrm{~km}$ altitude [6], we only show the time series of hourly AE profiles below $2 \mathrm{~km}$ in Figure $3 \mathrm{a}, \mathrm{b}$ and Supplementary Materials Figure S1. Besides higher AEs at lower altitudes, elevated AE layers are found frequently. The time series of AODs and AEs in the 0-50 m layer, integrated and extracted from the retrieved profiles respectively, are shown in Figure 3c,d. The average AOD and near-surface AE, i.e. $0.51 \pm 0.26$ and $0.33 \pm 0.18 \mathrm{~km}^{-1}$, over the campaign period are slightly smaller than the levels at the nearby suburban site of Xingtai (AOD: 0.65, AE: $0.43 \mathrm{~km}^{-1}$ in May and June 2016) [50]. The time series of AODs and near-surface AEs present similar variation trends with a correlation coefficient of $\mathrm{R}=0.78$ (Figure 4a). The variations of AOD and near-surface AE present several enhancement events, such as during the period of 27 June- 9 July, which can be used to indicate the pollution episodes. Both AODs and near-surface AEs are positively correlated 
with relative humidity (RH, Figures 3e and $4 \mathrm{~b}$ ), implying an influence of the aerosol hygroscopicity on the AE. Linear regression analysis shows that the correlation coefficient between near-surface AEs and RHs $(R=0.42)$ is larger than that between AOD and RHs $(R=0.32)$ (Figure $4 b)$. Surface in-situ measurements confirm that hygroscopic growth noticeably enhances the aerosol scattering coefficient at Raoyang, especially for conditions of high content of water-soluble secondary inorganic aerosols and fine particles $[19,64]$. The wind direction and speed have an important impact on the AE by transport of pollutants from different emission sources. For example, from the period of high AOD and near-surface AE ( 8 July) to the clean period (9 July), the RH stayed constantly around $60 \%$, but the wind direction changed from the southeast (more pollution) to the WNW section (less pollution), with the average wind speed increasing from $1.56 \mathrm{~m} / \mathrm{s}$ to $3.80 \mathrm{~m} / \mathrm{s}$ (Figure 3f).
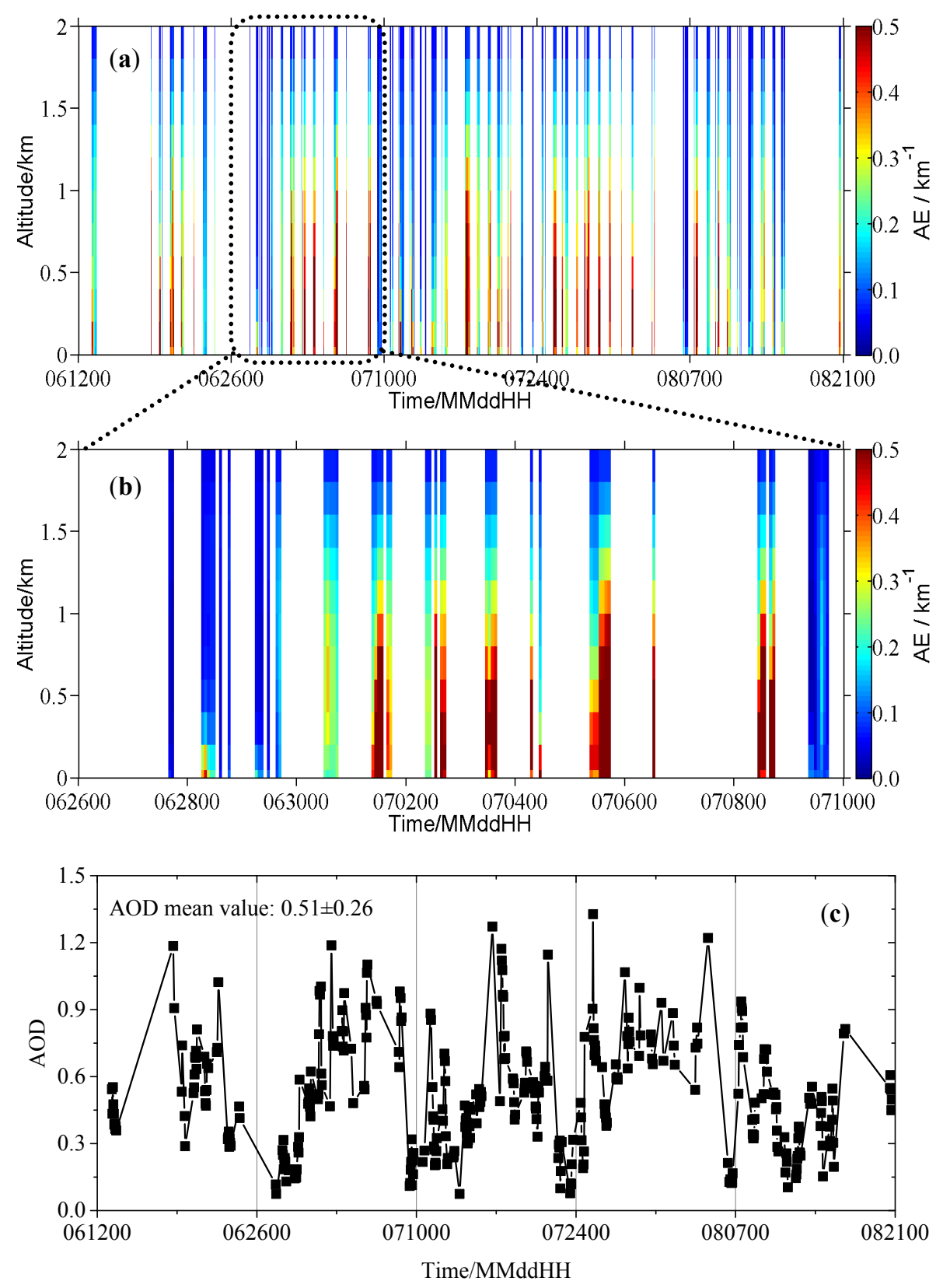

Figure 3. Cont. 

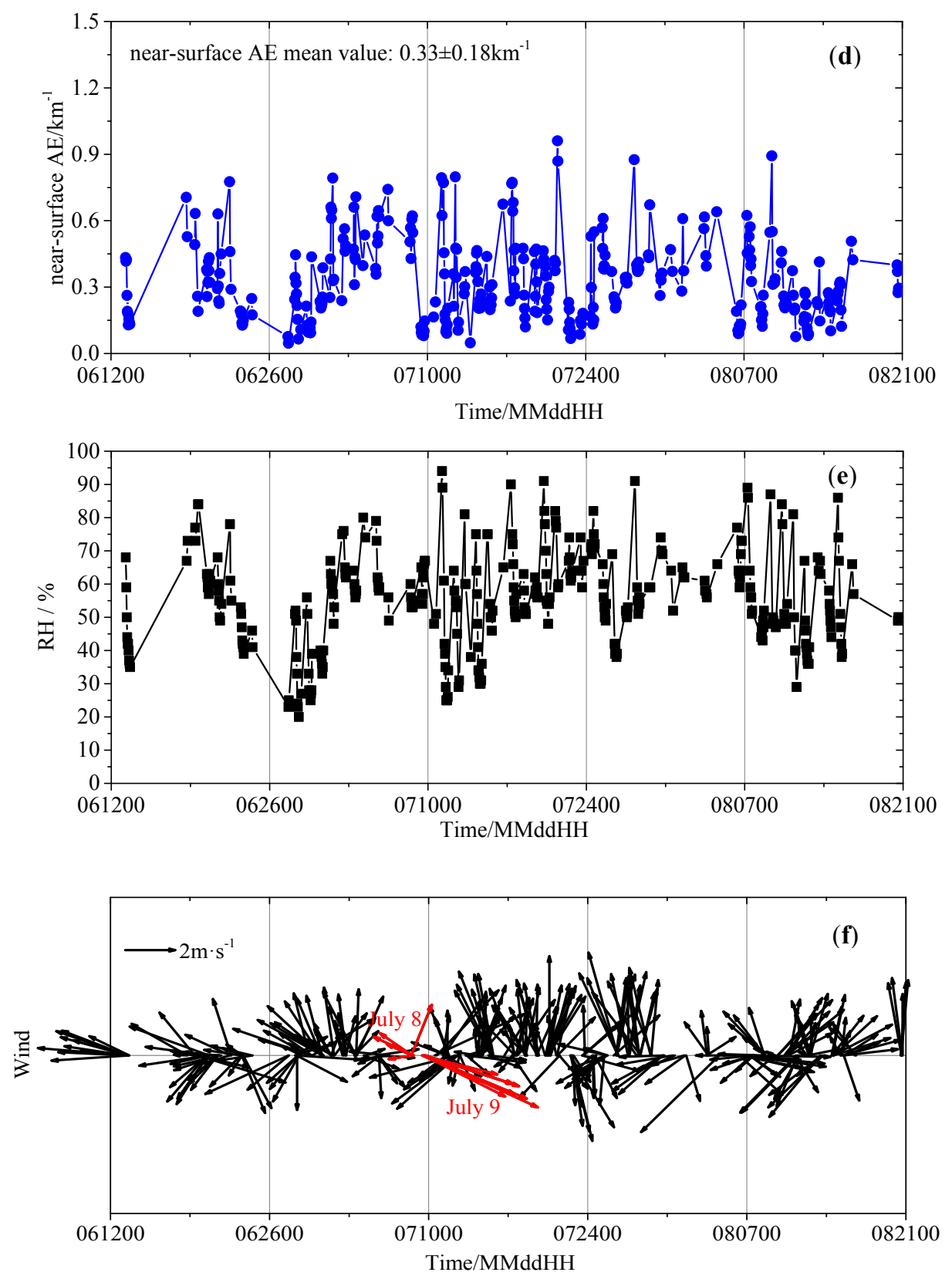

Figure 3. Time series of the qualified hourly average multi-axis differential optical absorption spectroscopy (MAX-DOAS) results and meteorological variables: (a) aerosol extinction (AE) profiles from MAX-DOAS for the experimental period; (b) enlarged AE profiles for the period marked by the black rectangle in panel (a); (c) aerosol optical depth (AOD) and (d) near-surface AE from MAX-DOAS for the experimental period; (e) in situ surface relative humidity (RH) and (f) in situ surface wind direction (WD) and wind speed (WS) with the scale of WS $=2 \mathrm{~m} \cdot \mathrm{s}^{-1}$ for the experimental period. The numbers, given in the Figure $3 c$, d denote the means \pm 1 standard deviation of AODs (dimensionless quantity) and AEs (Unit: $\mathrm{km}^{-1}$ ) during the observational period. The red arrows in Figure $3 f$ present the wind on 8 July and 9 July, respectively. 


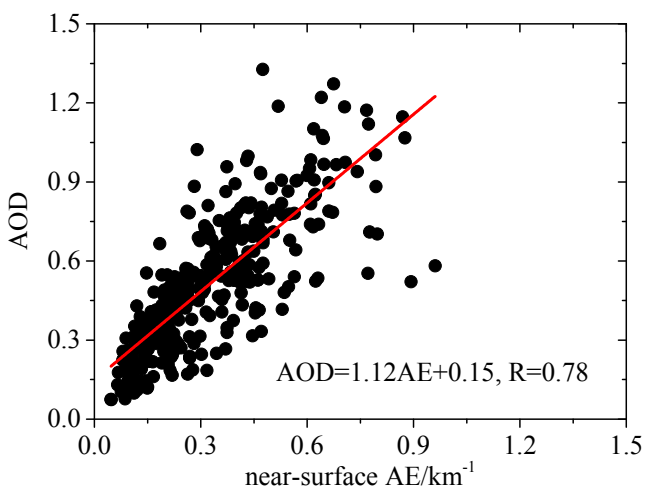

(a)

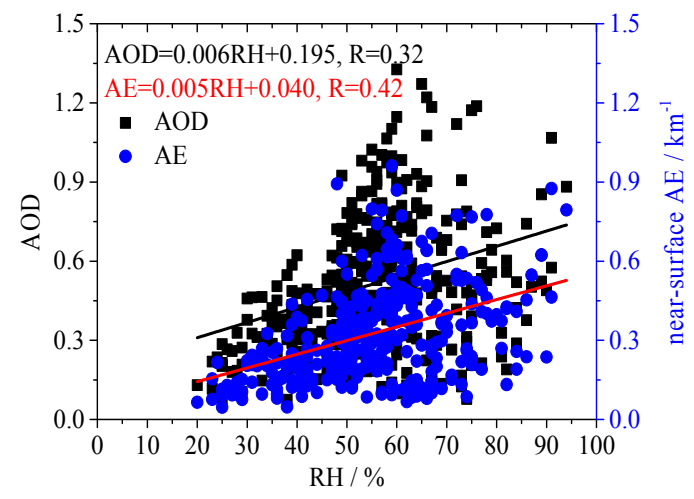

(b)

Figure 4. Correlations of the qualified hourly average MAX-DOAS results and meteorological variables: (a) correlation between AOD and near-surface AE; (b) correlation between AOD (near-surface AE) and $\mathrm{RH}$. The equations of linear regression and corresponding correlation coefficients ( $\mathrm{R}$ ) are also shown in Figure $4 a, b$.

To further investigate the influence of the wind direction and speed, we present the corresponding roses (Figure 5) using the hourly data shown above (Figure 3). During the observation period, the frequent wind directions (WD) were in the sectors of S, SSE, NE, and SSW (Figure 5a). Hourly wind speeds (WS) larger than $5 \mathrm{~m} / \mathrm{s}$ appeared in the WNW sector, and the average WS in all 16 WD sectors were between $1.6 \mathrm{~m} / \mathrm{s}$ and $3.0 \mathrm{~m} / \mathrm{s}$. Among the 16 wind directions (Figure $5 \mathrm{~b}, \mathrm{c}$ ), the highest frequencies of the largest ( $\mathrm{AOD}>1, \mathrm{AE}>0.75 \mathrm{~km}^{-1}$ ) and smallest $\left(\mathrm{AOD}<0.2, \mathrm{AE}<0.15 \mathrm{~km}^{-1}\right.$ ) values occurred in the sectors of NE and WNW, respectively. Both AODs and near-surface AEs varied strongly with wind direction (Figure 5d). In the NE to SSW sectors, the AOD (near-surface AE) means are high and close to each other, possibly connected with the cities distributed in these directions. Similarly, high AOD (near-surface AE) is also found in the NW sector, where Baoding city is located upstream (Figure 1b). Furthermore, to analyze the influences of pollutant transport, we calculated the weighted AOD and near-surface AE by the occurrence frequency of WD (Figure 5e). The highest weighted AOD and near-surface AE are concentrated on the directions of NE, SSE, S, and SSW, indicating that pollutants from the northeast and south, where cities with high source emissions are distributed [52], contribute significantly to the AE level at the Raoyang station. Figure $5 \mathrm{f}$ also shows the change of correlation coefficient between AOD and near-surface AE with the wind direction. Most of correlation coefficients are near to or higher than 0.8. Excluding the NW, WSW, and ENE cases for the reason of few samples, weaker correlation in the NE may be caused by the heterogeneous distribution of AE in the vertical profiles. Therefore, the wind field, coupled with inhomogeneous spatio-temporal emission sources, could significantly impact the vertical distribution of the AE. 


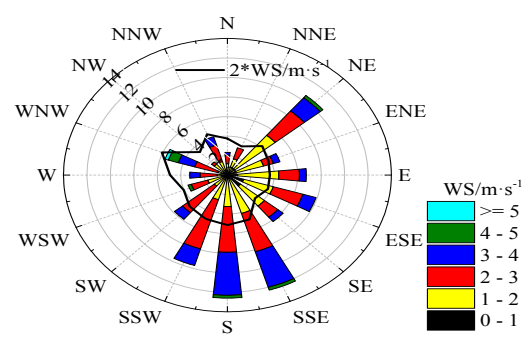

(a)

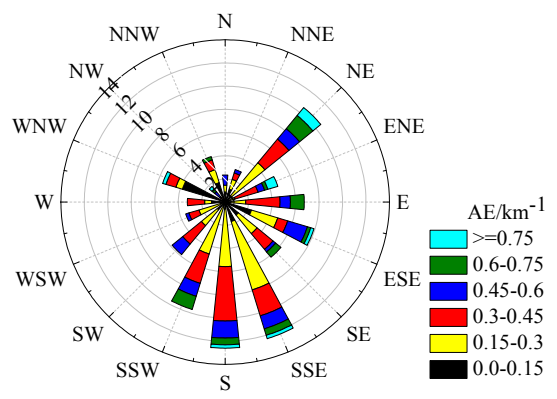

(c)

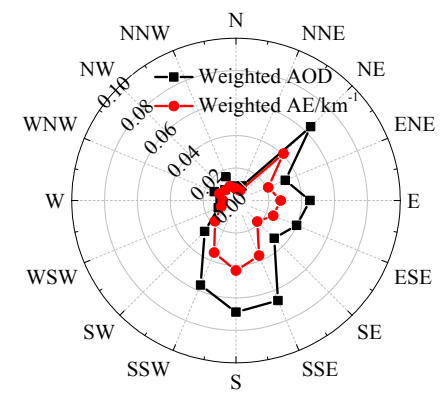

(e)

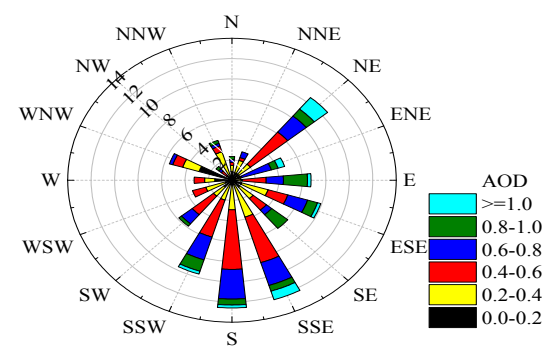

(b)

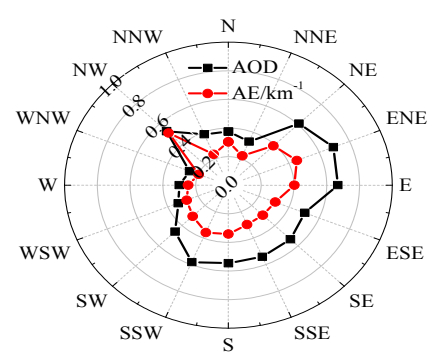

(d)

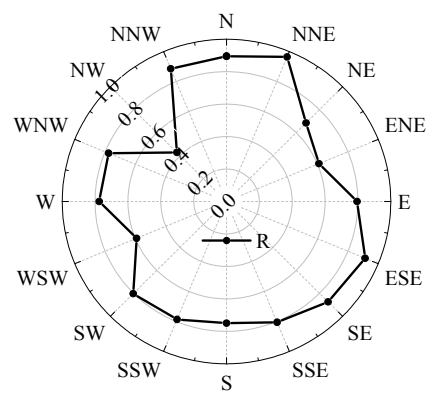

(f)

Figure 5. Roses for hourly wind, AOD and near-surface AE: (a) rose for wind frequency (color blocks; unit: \%) and wind speed (WS, black line, scaled by factor 2) in 16 wind direction sectors; roses for (b) AOD and (c) near-surface AE frequency (unit: \%); (d) averaged AODs and AEs, and (e) they are weighted by the wind frequency in 16 wind direction sectors; ( $f$ ) correlation coefficient ( $R$, black curve with dots) between $\mathrm{AOD}$ and $\mathrm{AE}$, respectively, on 16 wind directions.

\subsection{Diurnal Variations}

Diurnal pattern of AE profiles, as well as associated AODs and near-surface AEs, are shown in Figure 6a-c. Averaged over the observational period, the hourly mean AOD varies from 0.3 to 0.6 , reaching the minimum around 9:00 LT and sustaining at a high level of $\sim 0.5$ at 11:00-18:00 LT (Figure 6a). The hourly mean AE also reaches a low value at 8:00-9:00 LT, but it gradually decreases after reaching a peak at 11:00 LT (Figure 6b). The correlation coefficient of hourly mean values between AOD and near-surface AE diurnal variation is 0.32. During the period of 6:00-19:00 LT (Figure 6c), the lifted AE layers occurred for $10 \mathrm{~h}$ (7:00, 10:00-18:00 LT). Therefore, the difference in the diurnal pattern between the $\mathrm{AOD}$ and near-surface $\mathrm{AE}$ is significant, which can be attributed to the non-uniform distribution of $\mathrm{AE}$ in the vertical direction. In addition, high AOD and near-surface AE occurred in early morning (6:00-7:00 LT). Previous studies indicated that the loading of black carbon aerosols within the mixing layer was highest in the early morning, leading to strong absorption below $200 \mathrm{~m}$ and possibly high AOD and near-surface AE at that time [52]. The high AEs below $200 \mathrm{~m}$ at 6:00-7:00 (Figure 6c) were also possibly connected with the favorable conditions for aerosol hygroscopic growth in the early morning 
at high RH (Figure 6d) [22]. Similarly, the low AE value at 9:00 LT can also be attributed to low RH (Figure $6 \mathrm{~b}, \mathrm{~d})$. The wind direction changes within the sectors of SSW-E $\left(\sim 202-90^{\circ}\right)$, with a maximum wind speed of $2.5 \mathrm{~m} / \mathrm{s}$ at 14:00LT (Figure 6e). There is no distinct relationship for the diurnal variations between aerosol extinction and wind, which is probably related to the relatively small wind speed. The planetary boundary layer begins to develop from 8:00 LT until its peak height of $1.65 \mathrm{~km}$ at 14:00 LT (Figure 6f). It is clear that the AODs do not change with the planetary boundary layer height (PBLH) during the period 11:00-18:00 LT, but the AE profiles are basically within a fully developed convective boundary layer. The correlation coefficients (R, Figure 6f) indicate the consistency of AE variation between the surface and vertical column upward. The R minimum at 10:00 LT may be caused by the vertical structure of $\mathrm{AE}$ profile, such as the elevated AE layer. Overall, the obvious diurnal variations in the AOD, near-surface $\mathrm{AE}$, and the AE profile at the Raoyang station are associated with both the source emission and meteorological conditions (RH and PBLH).
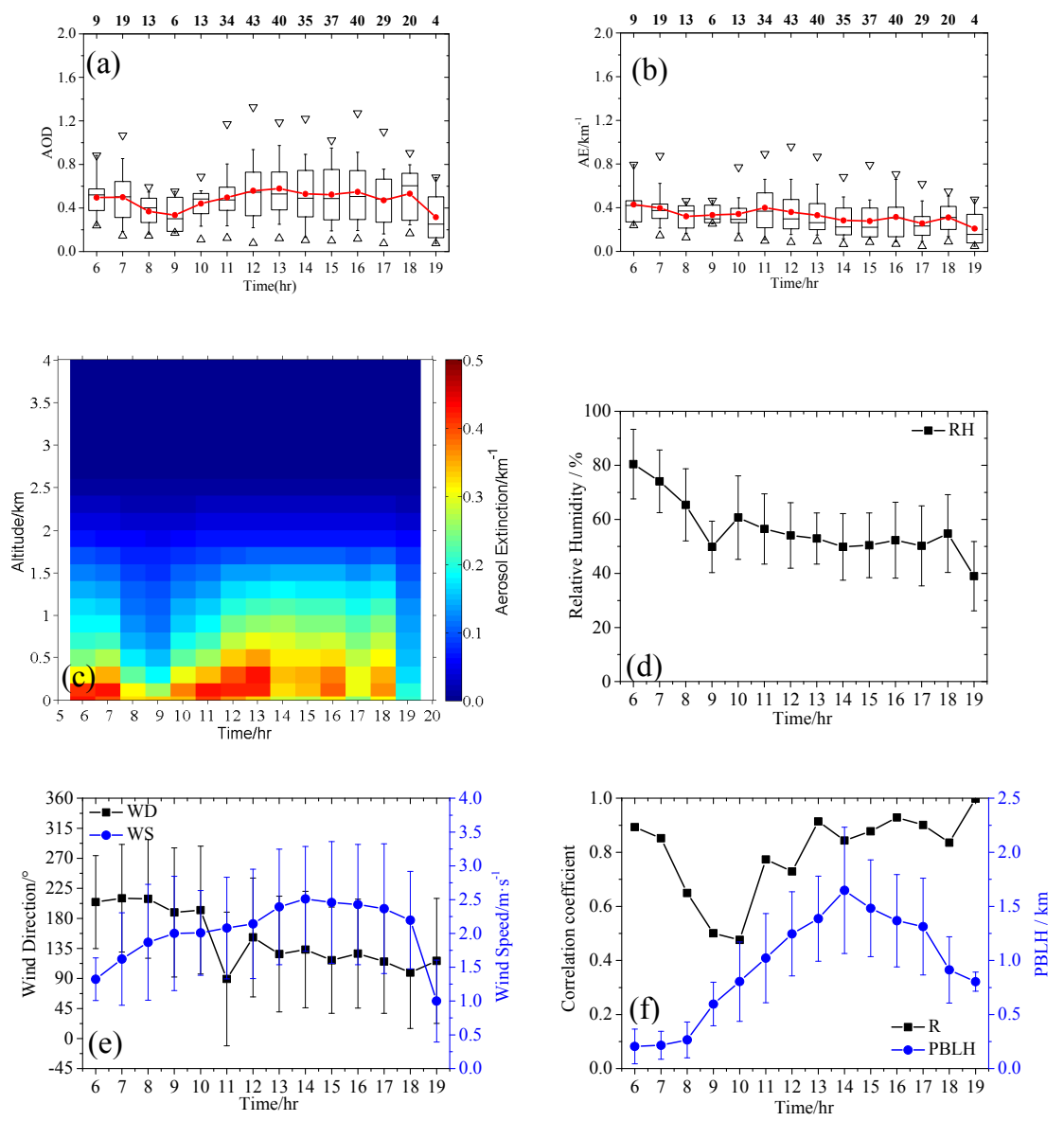

Figure 6. Diurnal variations of (a) AOD, (b) near-surface AE and (c) AE vertical profile based on the qualified hourly MAX-DOAS data, as well as (d) relative humidity (RH), (e) wind direction (WD) and wind speed (WS) from corresponding in-situ surface observations, (f) planetary boundary layer height (PBLH) and the correlation coefficients (R) between AOD and near-surface AE for each $h$. Lower (upper) error bars, boxes and lower (upper) triangles in Figure 6a,b are the 10th (90th), 25th (75th) percentiles, minima (maxima) of the data grouped in each $h$, respectively. Hyphens inside the boxes and curves with circles in Figure 6a,b separately denote the medians and the mean values. The numbers of integrated sampling days for specific $h$ are labeled at the top axis in Figure $6 a, b$. The error bars in Figure $6 \mathrm{~d}-\mathrm{f}$ denote standard deviations of RH, WD, WS, and PBLH for each $\mathrm{h}$, respectively. Note that the PBLH is from linearly interpolated reanalysis data with time interval of $3 \mathrm{~h}$ (https://www.ecmwf.int/en/forecasts/datasets/reanalysis-datasets/era5). 


\subsection{Average Vertical Profile of Aerosol Extinction and Comparison with Lidar}

Figure 7a shows the average vertical profile of AE obtained by MAX-DOAS for the whole observational period and the comparison with lidar extinction profiles. It should be noted that the MAX-DOAS AE profiles, retrieved by the optimal estimation method (OEM), are the true extinction profiles weighted by so-called averaging kernel (AK) matrix [65]. The AK matrix quantifies the sensitivity of the retrieved profile to the true atmospheric profile. For comparison, we also show the lidar AE profile with AK weighting in Figure 7a. It is clear that the AK weighting smooths the lidar measurement. As a whole, the weighted lidar extinction profile presents a relatively good agreement with MAX-DOAS. Both of them found the lifted AE layers, indicating aerosol accumulation, secondary formation or long-range transport at higher altitudes [50]. The qualitative comparisons at a suburban background site over Athens, Greece, also showed an encouraging agreement in aerosol layer shape between MAX-DOAS and lidar [39]. However, there are still some differences with respect to the vertical distribution structure derived by the two measurement methods, such as the height of the lifted layer, the absolute $\mathrm{AE}$ level, and the $\mathrm{AE}$ vertical gradient. The differences of the average $\mathrm{AE}$ profiles are at least partly impacted by three aspects. Firstly, for the extraction of the AE profiles from the commercial EZ aerosol lidar a default lidar ratio is used, which can be substantially different from the truth due to the variation of aerosol type. In consequence, the uncertainties of the absolute values of the AE profile might reach $20 \%[39,63,66]$. Secondly, it should be noted that in this study no scaling factor for the $\mathrm{O}_{4}$ dSCDs was applied during the MAX-DOAS inversion. There is still no consensus on the need of such a scaling factor (e.g., [67]), and in our study we did not find it necessary to apply such a scaling factor. Nevertheless, it might be worth mentioning that the application of a scaling factor (e.g., 0.8 like in Beijing; [35]) would be applied, the derived AE values would be systematically increased, leading to a better agreement between the two observation methods. Finally, since clouds were not explicitly filtered, remaining cloud contamination might also have an impact on the MAX-DOAS results.

For hourly AE profiles, there is still a consistency between MAX-DOAS and lidar with a correlation coefficient of $R=0.63$, although they are different at the high level of $A E>2 \mathrm{~km}^{-1}$ (Figure $7 \mathrm{~b}$ ). Based on the correlation of hourly AE profiles between MAX-DOAS and lidar, we found that higher correlation appears when the AOD from MAX-DOAS and RH are higher (Figure 7c,d). At present, we cannot explain why there are such differences in the correlation between the two methods under such different environmental conditions. Anyhow, in contrast to the limitations of lidar, blind region in particular, MAX-DOAS can serve as a supplement to observe the AE profiles in the lower troposphere [40]. 


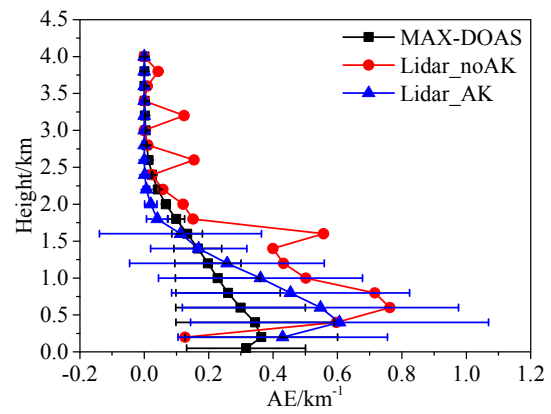

(a)

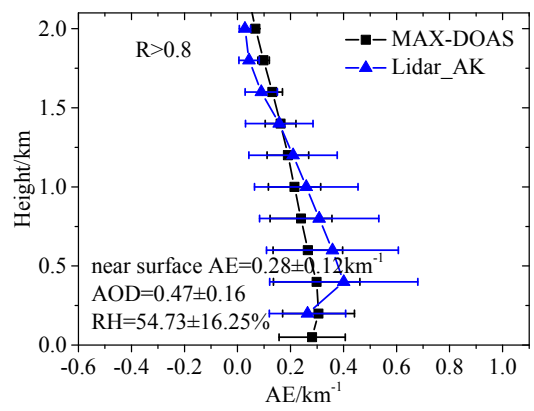

(c)

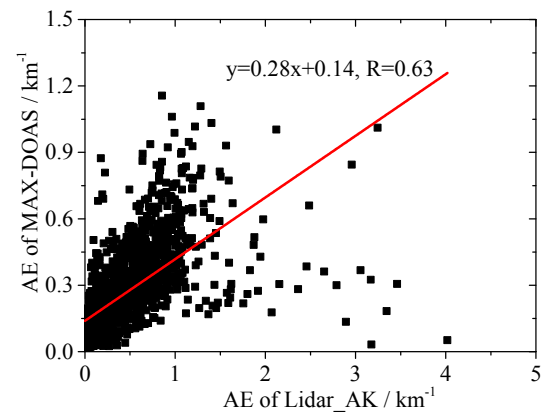

(b)

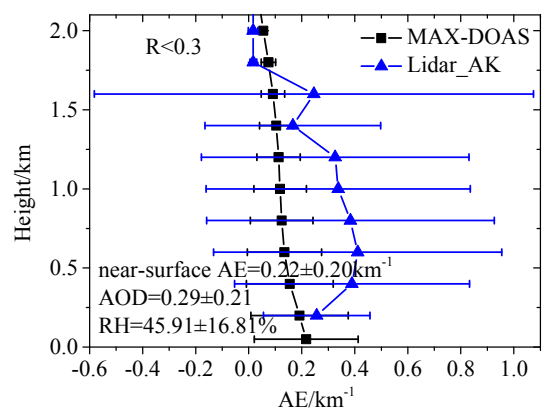

(d)

Figure 7. Vertical profiles of aerosol extinction (AE) during the whole observation period. (a) The black curve with squares denotes the average profile based on all the qualified MAX-DOAS results. Correspondingly, the curves with red dots (blue triangles) present the lidar results at the same time without (with) MAX-DOAS averaging kernel (AK) weighting. (b) The correlation between MAX-DOAS and lidar_AK for all the hourly AE profiles below $2.5 \mathrm{~km}$ altitude. The red line denotes the linear regression. Also shown is the linear equation and correlation coefficient (R). (c) AE profiles separately averaged from hourly MAX-DOAS and lidar_AK data when their correlation coefficients are larger than 0.8 . The equations present the corresponding mean values \pm standard deviations of MAX-DOAS AOD, near surface AE, and RH. (d) As (c), but for $\mathrm{R}<0.3$. The error bars for MAX-DOAS and lidar_AK in panels a,c,d denote the standard deviations. Lidar vertical profiles of AE with vertical resolution of $15 \mathrm{~m}$ are interpolated into MAX-DOAS retrieval height.

\section{Conclusions}

Ground-based MAX-DOAS and lidar measurements were performed during the VOGA field campaign in summer (13 June-20 August) 2014 at Raoyang $\left(115^{\circ} 44^{\prime} \mathrm{E}, 38^{\circ} 14^{\prime} \mathrm{N}\right.$ ), a rural site in the North China Plain. The aerosol extinction (AE) vertical profiles in the lower troposphere were retrieved through QDOAS software (http://uv-vis.aeronomie.be/software/QDOAS/) spectral analysis and PriAM profile inversion. We analyzed the time series and diurnal variation of AE profiles, near-surface AE, and AODs during the field campaign. We also compared the AE profile retrieved by MAX-DOAS with that measured by lidar. The main findings are summarized below.

1. The average AOD and near-surface AE were $0.51 \pm 0.26$ and $0.33 \pm 0.18 \mathrm{~km}^{-1}$ during the effective observation period, respectively. The time series of AODs and near-surface AEs presented similar variation trends, with several high value events occurring simultaneously. From the time series of AE profile, elevated AE layers were found to occur frequently. Both AODs and near-surface AEs were positively correlated with the relative humidity (correlation coefficient $\mathrm{R}=0.32,0.42$, respectively).

2. The AOD and near-surface AE roses show that there are significant differences for averages of AODs and near-surface AEs in 16 wind sectors, with higher AOD or AE means often occurring in 
the upstream directions of cities. The weighted AOD and AE indicated that pollutant transport from the northeast and south contributes significantly to the AE level at the Raoyang station. The correlation coefficient between AODs and near-surface AEs depends on the wind direction. The low correlation in NE sector implies heterogeneous distribution of $\mathrm{AE}$ in the vertical direction. Therefore, the wind field and spatio-temporal distribution of emission sources significantly impact the near-surface $\mathrm{AE}, \mathrm{AOD}$, and $\mathrm{AE}$ profile.

3. The average diurnal variations of AE profile, AODs and near-surface AE were significantly correlated, due to synchronized effects of the source emission and meteorological condition. The correlation coefficients between the AOD and near-surface AE presented the minimum at 10:00 LT. This was due to the influence of lifted AE layers. The AODs were sustained at a high level of $\sim 0.5$ during 11:00-18:00 LT, while near-surface AE gradually decreases after 11:00 LT. The differences can be attributed to the development of the convective boundary layer.

4. The shape of the AE profiles derived by the MAX-DOAS and the lidar were in agreement. The two quantities revealed the lifted AE layers. However, the height of the lifted layer, the absolute AE level, and the AE vertical gradient were different between the two methods (MAX-DOAS and lidar). The differences were probably connected with the lidar and MAX-DOAS retrievals of the $\mathrm{AE}$ profiles, such as the use of a default lidar ratio and the possible uncertainties related to the application (or not) of a scaling factor for the $\mathrm{O}_{4} \mathrm{dSCDs}$. Based on the correlation of hourly AE profiles between MAX-DOAS and lidar, we also found that high correlation appeared when the AOD from MAX-DOAS and RH were higher. As a whole, MAX-DOAS can serve as a supplement to provide AE vertical profiles in the lower troposphere $(0-2 \mathrm{~km})$.

Supplementary Materials: The following are available online at http://www.mdpi.com/2073-4433/11/10/1037/ s1, Figure S1: Time series of enlarged AE profiles for different time segments: (a) 12 June-26 June 2014; (b) 26 June-10 July 2014; (c) 10 July-24 July 2014; (d) 24 July-7 August 2014; (e) 7 August-21 August 2014.

Author Contributions: Conceptualization, S.C., J.M. and T.W.; methodology, Y.W. and T.W.; software, S.C. and Y.W.; formal analysis, S.C. and J.M.; investigation, J.J., Z.M. and J.G.; resources, J.M. and Z.M.; data curation, S.C., L.R. and J.C.; writing-original draft preparation, S.C.; writing—review and editing, S.C., J.M., X.X. and T.W.; visualization, S.C. and P.Y.; supervision, J.M.; project administration, X.X.; funding acquisition, X.X. and J.J. All authors have read and agreed to the published version of the manuscript.

Funding: This work was supported by the National Natural Science Foundation of China (Nos. 41330422, 41805027, 41875146) and the National Key Research and Development Program of China (No. 2017YFC1501702).

Acknowledgments: We thank the staff at the Raoyang Meteorological Bureau for supporting the measurements. We thank NASA for the MODIS AOD products. We thank ECMWF for the reanalysis meteorological products. We also thank the DOAS UV-VIS team at BIRA-IASB for QDOAS software of spectral analysis.

Conflicts of Interest: The authors declare that they have no conflict of interest. The funders had no role in the design of the study; in the collection, analyses, or interpretation of data; in the writing of the manuscript; or in the decision to publish the results.

\section{References}

1. Lu, X.; Zhang, S.; Xing, J.; Wang, Y.; Chen, W.; Ding, D.; Wu, Y.; Wang, S.; Duan, L.; Hao, J. Progress of Air Pollution Control in China and Its Challenges and Opportunities in the Ecological Civilization Era. Engineering 2020. [CrossRef]

2. Zhong, J.; Zhang, X.; Dong, Y.; Wang, Y.; Liu, C.; Wang, J.; Zhang, Y.; Che, H. Feedback effects of boundary-layer meteorological factors on cumulative explosive growth of PM2.5 during winter heavy pollution episodes in Beijing from 2013 to 2016. Atmos. Chem. Phys. Discuss. 2018, 18, 247-258. [CrossRef]

3. Ma, J.; Chen, Y.; Wang, W.; Yan, P.; Liu, H.; Yang, S.; Hu, Z.; Lelieveld, J. Strong air pollution causes widespread haze-clouds over China. J. Geophys. Res. Space Phys. 2010, 115. [CrossRef]

4. Stocker, T.F.; Qin, D.; Plattner, G.-K.; Alexander, L.V.; Allen, S.K.; Bindoff, N.L.; Bréon, F.-M.; Church, J.A.; Cubasch, U.; Emori, S.; et al. Technical Summary. In Climate Change 2013: The Physical Science Basis. Contribution of Working Group I to the Fifth Assessment Report of the Intergovernmental Panel on Climate Change; Cambridge University Press: Cambridge, UK, 2013; pp. 53-59. 
5. Sun, J.; Zhou, T. Health risk assessment of China's main air pollutants. BMC Public Health 2017, 17, 212. [CrossRef]

6. Li, Z.; Guo, J.; Ding, A.; Liao, H.; Liu, J.; Sun, Y.; Wang, T.; Xue, H.; Zhang, H.; Zhu, B. Aerosol and boundary-layer interactions and impact on air quality. Natl. Sci. Rev. 2017, 4, 810-833. [CrossRef]

7. Tao, J.; Zhang, L.; Cao, J.; Zhang, R. A review of current knowledge concerning PM2.5 chemical composition, aerosol optical properties and their relationships across China. Atmos. Chem. Phys. Discuss. 2017, 17, 9485-9518. [CrossRef]

8. Chen, H.; Xia, X.; Zhu, J.; Li, Z.; Dubovik, O.; Holben, B.; Goloub, P.; Estellés, V.; Cuevas-Agulló, E.; Blarel, L.; et al. Column aerosol optical properties and aerosol radiative forcing during a serious haze-fog month over North China Plain in 2013 based on ground-based sunphotometer measurements. Atmos. Chem. Phys. Discuss. 2014, 14, 2125-2138. [CrossRef]

9. Che, H.; Yang, L.; Liu, C.; Xia, X.; Wang, Y.; Wang, H.; Wang, H.; Lu, X.; Zhang, X. Long-term validation of MODIS C6 and C6.1 Dark Target aerosol products over China using CARSNET and AERONET. Chemosphere 2019, 236, 124268. [CrossRef]

10. Che, H.; Xia, X.; Zhao, H.; Dubovik, O.; Holben, B.N.; Goloub, P.; Cuevas-Agulló, E.; Estelles, V.; Wang, Y.; Zhu, J.; et al. Spatial distribution of aerosol microphysical and optical properties and direct radiative effect from the China Aerosol Remote Sensing Network. Atmos. Chem. Phys. Discuss. 2019, 19, 11843-11864. [CrossRef]

11. Li, C.; Li, J.; Dubovik, O.; Zeng, Z.-C.; Yung, Y.L. Impact of Aerosol Vertical Distribution on Aerosol Optical Depth Retrieval from Passive Satellite Sensors. Remote. Sens. 2020, 12, 1524. [CrossRef]

12. Zhang, S.; Wu, J.; Fan, W.; Yang, Q.; Zhao, D. Review of aerosol optical depth retrieval using visibility data. Earth-Sci. Rev. 2020, 200, 102986. [CrossRef]

13. Ma, J.; Xu, X.; Zhao, C.; Yan, P. A review of atmospheric chemistry research in China: Photochemical smog, haze pollution, and gas-aerosol interactions. Adv. Atmos. Sci. 2012, 29, 1006-1026. [CrossRef]

14. Zheng, Y.; Che, H.; Xia, X.; Wang, Y.; Wang, H.; Wu, Y.; Tao, J.; Zhao, H.; An, L.; Li, L.; et al. Five-year observation of aerosol optical properties and its radiative effects to planetary boundary layer during air pollution episodes in North China: Intercomparison of a plain site and a mountainous site in Beijing. Sci. Total Environ. 2019, 674, 140-158. [CrossRef] [PubMed]

15. Xia, X.; Che, H.; Zhu, J.; Chen, H.; Cong, Z.; Deng, X.; Fan, X.; Fu, Y.; Goloub, P.; Jiang, H.; et al. Ground-based remote sensing of aerosol climatology in China: Aerosol optical properties, direct radiative effect and its parameterization. Atmos. Environ. 2016, 124, 243-251. [CrossRef]

16. Che, H.; Zhang, X.-Y.; Xia, X.; Goloub, P.; Holben, B.; Zhao, H.; Wang, Y.; Wang, H.; Blarel, L.; Damiri, B.; et al. Ground-based aerosol climatology of China: Aerosol optical depths from the China Aerosol Remote Sensing Network (CARSNET) 2002-2013. Atmos. Chem. Phys. Discuss. 2015, 15, 7619-7652. [CrossRef]

17. Yan, P.; Tang, J.; Huang, J.; Mao, J.T.; Zhou, X.J.; Liu, Q.; Wang, Z.F.; Zhou, H.G. The measurement of aerosol optical properties at a rural site in Northern China. Atmos. Chem. Phys. Discuss. 2008, 8, 2229-2242. [CrossRef]

18. Zhang, L.; Yan, P.; Mao, J.; Zhang, X.; Tian, P.; Chang, H. Observational Study on Aerosol Scattering Phase Function at Raoyang of Hebei, China. J. Appl. Meteorol. Sci. 2017, 28, 436-446.

19. Wu, Y.; Wang, X.; Yan, P.; Zhang, L.; Tao, J.; Liu, X.; Tian, P.; Han, Z.; Zhang, R. Investigation of hygroscopic growth effect on aerosol scattering coefficient at a rural site in the southern North China Plain. Sci. Total Environ. 2017, 599, 76-84. [CrossRef]

20. Wang, F.; Li, Z.; Ren, X.; Jiang, Q.; He, H.; Dickerson, R.R.; Dong, X.; Lv, F. Vertical distributions of aerosol optical properties during the spring 2016 ARIAs airborne campaign in the North China Plain. Atmos. Chem. Phys. Discuss. 2018, 18, 8995-9010. [CrossRef]

21. Tian, P.; Liu, D.; Zhao, D.; Yu, C.; Liu, Q.; Huang, M.; Deng, Z.; Ran, L.; Wu, Y.; Ding, S.; et al. In situ vertical characteristics of optical properties and heating rates of aerosol over Beijing. Atmos. Chem. Phys. Discuss. 2020, 20, 2603-2622. [CrossRef]

22. Wang, R.; Xu, X.; Jia, S.; Ma, R.; Ran, L.; Deng, Z.; Lin, W.; Wang, Y.; Ma, Z. Lower tropospheric distributions of $\mathrm{O}_{3}$ and aerosol over Raoyang, a rural site in the North China Plain. Atmos. Chem. Phys. Discuss. 2017, 17, 3891-3903. [CrossRef] 
23. Liu, Q.; Liu, D.; Gao, Q.; Tian, P.; Wang, F.; Zhao, D.; Bi, K.; Wu, Y.; Ding, S.; Hu, K.; et al. Vertical characteristics of aerosol hygroscopicity and impacts on optical properties over the North China Plain during winter. Atmos. Chem. Phys. Discuss. 2020, 20, 3931-3944. [CrossRef]

24. Chen, Z.; Liu, C.; Liu, W.; Zhang, T.; Xu, J. A synchronous observation of enhanced aerosol and $\mathrm{NO}_{2}$ over Beijing, China, in winter 2015. Sci. Total. Environ. 2017, 575, 429-436. [CrossRef] [PubMed]

25. Tesche, M.; Ansmann, A.; Müller, D.; Althausen, D.; Engelmann, R.; Hu, M.; Zhang, Y.; Müller, D. Particle backscatter, extinction, and lidar ratio profiling with Raman lidar in south and north China. Appl. Opt. 2007, 46, 6302-6308. [CrossRef]

26. Xie, C.; Xu, W.; Wang, J.; Wang, Q.; Liu, D.; Tang, G.; Chen, P.; Du, W.; Zhao, J.; Zhang, Y.; et al. Vertical characterization of aerosol optical properties and brown carbon in winter in urban Beijing, China. Atmos. Chem. Phys. Discuss. 2019, 19, 165-179. [CrossRef]

27. Wang, Q.; Sun, Y.; Xu, W.; Du, W.; Zhou, L.; Tang, G.; Chen, C.; Cheng, X.; Zhao, X.; Ji, D.; et al. Vertically resolved characteristics of air pollution during two severe winter haze episodes in urban Beijing, China. Atmos. Chem. Phys. Discuss. 2018, 18, 2495-2509. [CrossRef]

28. Bian, Y.; Xu, W.; Hu, Y.; Tao, J.; Kuang, Y.; Zhao, C. Method to retrieve aerosol extinction profiles and aerosol scattering phase functions with a modified CCD laser atmospheric detection system. Opt. Express 2020, 28, 6631-6647. [CrossRef]

29. Hönninger, G.; Von Friedeburg, C.; Platt, U. Multi axis differential optical absorption spectroscopy (MAX-DOAS). Atmos. Chem. Phys. Discuss. 2004, 4, 231-254. [CrossRef]

30. Halla, J.D.; Wagner, T.; Beirle, S.; Brook, J.R.; Hayden, K.L.; O’Brien, J.M.; Ng, A.; Majonis, D.; Wenig, M.O.; McLaren, R. Determination of tropospheric vertical columns of $\mathrm{NO}_{2}$ and aerosol optical properties in a rural setting using MAX-DOAS. Atmos. Chem. Phys. Discuss. 2011, 11, 12475-12498. [CrossRef]

31. Härtl, A.; Wenig, M.O. Regularisation model study for the least-squares retrieval of aerosol extinction time series from UV/VIS MAX-DOAS observations for a ground layer profile parameterisation. Atmos. Meas. Tech. 2013, 6, 1959-1980. [CrossRef]

32. Li, X.; Brauers, T.; Shao, M.; Garland, R.M.; Wagner, T.; Deutschmann, T.; Wahner, A. MAX-DOAS measurements in southern China: Retrieval of aerosol extinctions and validation using ground-based in-situ data. Atmos. Chem. Phys. Discuss. 2010, 10, 2079-2089. [CrossRef]

33. Ortega, I.; Coburn, S.; Berg, L.K.; Lantz, K.; Michalsky, J.; Ferrare, R.A.; Hair, J.W.; Hostetler, C.A.; Volkamer, R. The CU 2-D-MAX-DOAS instrument-Part 2: Raman scattering probability measurements and retrieval of aerosol optical properties. Atmos. Meas. Tech. 2016, 9, 3893-3910. [CrossRef]

34. Wagner, T.; Dix, B.; Von Friedeburg, C.; Fries, U.; Sanghavi, S.; Sinreich, R.; Platt, U. MAX-DOAS O measurements: A new technique to derive information on atmospheric aerosols-Principles and information content. J. Geophys. Res. Space Phys. 2004, 109. [CrossRef]

35. Clémer, K.; Van Roozendael, M.; Fayt, C.; Hendrick, F.; Hermans, C.; Pinardi, G.; Spurr, R.; Wang, P.; De Mazière, M. Multiple wavelength retrieval of tropospheric aerosol optical properties from MAXDOAS measurements in Beijing. Atmos. Meas. Tech. 2010, 3, 863-878. [CrossRef]

36. Fries, U.; Monks, P.S.; Remedios, J.J.; Rozanov, A.; Sinreich, R.; Wagner, T.; Platt, U. MAX-DOAS $\mathrm{O}_{4}$ measurements: A new technique to derive information on atmospheric aerosols: 2. Modeling studies. J. Geophys. Res. Space Phys. 2006, 111. [CrossRef]

37. Irie, H.; Kanaya, Y.; Akimoto, H.; Iwabuchi, H.; Shimizu, A.; Aoki, K. First retrieval of tropospheric aerosol profiles using MAX-DOAS and comparison with lidar and sky radiometer measurements. Atmos. Chem. Phys. Discuss. 2008, 8, 341-350. [CrossRef]

38. Xing, C.; Liu, C.; Wang, S.; Hu, Q.; Liu, H.; Tan, W.; Zhang, W.; Li, B.; Liu, J. A new method to determine the aerosol optical properties from multiple-wavelength $\mathrm{O}_{4}$ absorptions by MAX-DOAS observation. Atmos. Meas. Tech. 2019, 12, 3289-3302. [CrossRef]

39. Gratsea, M.; Bösch, T.; Kokkalis, P.; Richter, A.; Vrekoussis, M.; Kazadzis, S.; Tsekeri, A.; Papayannis, A.; Mylonaki, M.; Amiridis, V.; et al. Retrieval and evaluation of tropospheric aerosol extinction profiles using MAX-DOAS measurements over Athens, Greece. Atmos. Meas. Tech. 2020, 2020, 1-30.

40. Davis, Z.Y.W.; Friess, U.; Strawbridge, K.B.; Aggarwaal, M.; Baray, S.; Schnitzler, E.G.; Lobo, A.; Fioletov, V.E.; Abboud, I.; McLinden, C.A.; et al. Validation of MAX-DOAS retrievals of aerosol extinction, $\mathrm{SO}_{2}$, and $\mathrm{NO}_{2}$ through comparison with lidar, sun photometer, active DOAS, and aircraft measurements in the Athabasca oil sands region. Atmos. Meas. Tech. 2020, 13, 1129-1155. [CrossRef] 
41. Chan, K.; Wiegner, M.; Wenig, M.; Pöhler, D. Observations of tropospheric aerosols and $\mathrm{NO}_{2}$ in $\mathrm{Hong}$ Kong over 5 years using ground based MAX-DOAS. Sci. Total Environ. 2018, 1545-1556. [CrossRef]

42. Irie, H.; Takashima, H.; Kanaya, Y.; Boersma, K.F.; Gast, L.; Wittrock, F.; Brunner, D.; Zhou, Y.; Van Roozendael, M. Eight-component retrievals from ground-based MAX-DOAS observations. Atmos. Meas. Tech. 2011, 4, 1027-1044. [CrossRef]

43. Mou, F.; Luo, J.; Li, S.; Shan, W.; Hu, L. Vertical profile of aerosol extinction based on the measurement of $\mathrm{O}_{4}$ of multi-elevation angles with MAX-DOAS. Chin. Phys. B 2019, 28, 084212. [CrossRef]

44. Wang, Y.; Li, A.; Xie, P.-H.; Chen, H.; Xu, J.; Wu, F.-C.; Liu, J.-G.; Liu, W.-Q. Retrieving vertical profile of aerosol extinction by multi-axis differential optical absorption spectroscopy. Acta Phys. Sin. 2013, 62, 180705.

45. Fries, U.; Baltink, H.K.; Beirle, S.; Clémer, K.; Hendrick, F.; Henzing, B.; Irie, H.; De Leeuw, G.; Li, A.; Moerman, M.M.; et al. Intercomparison of aerosol extinction profiles retrieved from MAX-DOAS measurements. Atmos. Meas. Tech. 2016, 9, 3205-3222. [CrossRef]

46. Gielen, C.; Hendrick, F.; Pinardi, G.; De Smedt, I.; Fayt, C.; Hermans, C.; Stavrakou, T.; Bauwens, M.; Müller, J.-F.; Ndenzako, E.; et al. Characterisation of Central-African aerosol and trace-gas emissions based on MAX-DOAS measurements and model simulations over Bujumbura, Burundi. Atmos. Chem. Phys. Discuss. 2017, 1-41. [CrossRef]

47. Wagner, T.; Beirle, S.; Brauers, T.; Deutschmann, T.; Fries, U.; Hak, C.; Halla, J.D.; Heue, K.-P.; Junkermann, W.; $\mathrm{Li}, \mathrm{X}$; ; et al. Inversion of tropospheric profiles of aerosol extinction and $\mathrm{HCHO}$ and $\mathrm{NO}_{2}$ mixing ratios from MAX-DOAS observations in Milano during the summer of 2003 and comparison with independent data sets. Atmos. Meas. Tech. 2011, 4, 2685-2715. [CrossRef]

48. Wang, S.; Cuevas, C.A.; Fries, U.; Saiz-Lopez, A. MAX-DOAS retrieval of aerosol extinction properties in Madrid, Spain. Atmos. Meas. Tech. 2016, 9, 5089-5101. [CrossRef]

49. Wang, T.; Wang, P.C. Assessment of MAX-DOAS aerosol retrieval over North China. Chin. J. Geophys. 2018, 61, 494-503.

50. Wang, Y.; Dörner, S.; Donner, S.; Böhnke, S.; De Smedt, I.; Dickerson, R.R.; Dong, Z.; He, H.; Li, Z.; $\mathrm{Li}$, Z.; et al. Vertical profiles of $\mathrm{NO}_{2}, \mathrm{SO}_{2}, \mathrm{HONO}, \mathrm{HCHO}, \mathrm{CHOCHO}$ and aerosols derived from MAX-DOAS measurements at a rural site in the central western North China Plain and their relation to emission sources and effects of regional transport. Atmos. Chem. Phys. Discuss. 2019, 19, 5417-5449. [CrossRef]

51. Peng, W.; Wang, Y.; Gao, X.; Jia, S.; Xu, X.; Cheng, H.; Meng, Z. Characteristics of Ambient Formaldehyde at Two Rural Sites in the North China Plain in Summer. Res. Environ. Sci. 2016, 29, 1119-1127.

52. Ran, L.; Deng, Z.; Xu, X.; Yan, P.; Lin, W.; Wang, Y.; Tian, P.; Wang, P.; Pan, W.; Lu, D. Vertical profiles of black carbon measured by a micro-aethalometer in summer in the North China Plain. Atmos. Chem. Phys. Discuss. 2016, 16, 10441-10454. [CrossRef]

53. Jin, J.; Ma, J.; Lin, W.; Zhao, H.; Shaiganfar, R.; Beirle, S.; Wagner, T. MAX-DOAS measurements and satellite validation of tropospheric $\mathrm{NO}_{2}$ and $\mathrm{SO}_{2}$ vertical column densities at a rural site of North China. Atmos. Environ. 2016, 133, 12-25. [CrossRef]

54. Cheng, S.; Ma, J.; Cheng, W.; Yan, P.; Zhou, H.; Zhou, L.; Yang, P. Tropospheric $\mathrm{NO}_{2}$ vertical column densities retrieved from ground-based MAX-DOAS measurements at Shangdianzi regional atmospheric background station in China. J. Environ. Sci. 2019, 80, 186-196. [CrossRef]

55. Ma, J.; Beirle, S.; Jin, J.L.; Shaiganfar, R.; Yan, P.; Wagner, T. Tropospheric $\mathrm{NO}_{2}$ vertical column densities over Beijing: Results of the first three years of ground-based MAX-DOAS measurements (2008-2011) and satellite validation. Atmos. Chem. Phys. Discuss. 2013, 13, 1547-1567. [CrossRef]

56. Ma, J.; Dörner, S.; Donner, S.; Jin, J.; Cheng, S.; Guo, J.; Zhang, Z.; Wang, J.; Liu, P.; Zhang, G.; et al. MAX-DOAS measurements of $\mathrm{NO}_{2}, \mathrm{SO}_{2}, \mathrm{HCHO}$, and $\mathrm{BrO}$ at the Mt. Waliguan WMO GAW global baseline station in the Tibetan Plateau. Atmos. Chem. Phys. Discuss. 2020, 20, 6973-6990. [CrossRef]

57. Brinksma, E.J.; Pinardi, G.; Volten, H.; Braak, R.; Richter, A.; Schönhardt, A.; Van Roozendael, M.; Fayt, C.; Hermans, C.; Dirksen, R.J.; et al. The 2005 and 2006 DANDELIONS $\mathrm{NO}_{2}$ and aerosol intercomparison campaigns. J. Geophys. Res. Space Phys. 2008, 113. [CrossRef]

58. Piters, A.J.M.; Boersma, K.F.; Kroon, M.; Hains, J.C.; Van Roozendael, M.; Wittrock, F.; Abuhassan, N.; Adams, C.; Akrami, M.; Allaart, M.A.F.; et al. The Cabauw Intercomparison campaign for Nitrogen Dioxide measuring Instruments (CINDI): Design, execution, and early results. Atmos. Meas. Tech. 2012, 5, 457-485. [CrossRef] 
59. Platt, U.; Stutz, J. Differential Optical Absorption Spectroscopy: Principles and Applications; Springer: Berlin/Heidelberg, Germany, 2008.

60. Wang, Y.; Lampel, J.; Xie, P.; Beirle, S.; Li, A.; Wu, D.; Wagner, T. Ground-based MAX-DOAS observations of tropospheric aerosols, $\mathrm{NO}_{2}, \mathrm{SO}_{2}$ and $\mathrm{HCHO}$ in Wuxi, China, from 2011 to 2014. Atmos. Chem. Phys. Discuss. 2017, 17, 2189-2215. [CrossRef]

61. Wang, Y.; De Vries, M.J.M.P.; Xie, P.H.; Beirle, S.; Dörner, S.; Remmers, J.; Li, A.; Wagner, T. Cloud and aerosol classification for 2.5 years of MAX-DOAS observations in Wuxi (China) and comparison to independent data sets. Atmos. Meas. Tech. 2015, 8, 5133-5156. [CrossRef]

62. Wagner, T.; Apituley, A.; Beirle, S.; Dörner, S.; Fries, U.; Remmers, J.; Shaiganfar, R. Cloud detection and classification based on MAX-DOAS observations. Atmos. Meas. Tech. 2014, 7, 1289-1320. [CrossRef]

63. Wang, Y.; Miao, S.; Zhang, X. Study on atmospheric pollution characteristics before a snowfall event in autumn in the Beijing urban area using lidar. Clim. Environ. Res. 2014, 19, 659-669.

64. Bove, M.; Brotto, P.; Calzolai, G.; Cassola, F.; Cavalli, F.; Fermo, P.; Hjorth, J.; Massabò, D.; Nava, S.; Piazzalunga, A.; et al. PM10 source apportionment applying PMF and chemical tracer analysis to ship-borne measurements in the Western Mediterranean. Atmos. Environ. 2016, 125, 140-151. [CrossRef]

65. Córdoba-Jabonero, C.; Andrey-Andrés, J.; Gómez-Martín, L.; Adame, J.A.; Sorribas, M.; Navarro-Comas, M.; Puentedura, O.; Cuevas-Agulló, E.; Gil-Ojeda, M. Vertical mass impact and features of Saharan dust intrusions derived from ground-based remote sensing in synergy with airborne in-situ measurements. Atmos. Environ. 2016, 142, 420-429. [CrossRef]

66. Sasano, Y.; Browell, E.V.; Ismail, S. Error caused by using a constant extinction/backscattering ratio in the lidar solution. Appl. Opt. 1985, 24, 3929-3932. [CrossRef]

67. Wagner, T.; Beirle, S.; Benavent, N.; Bösch, T.; Chan, K.L.; Donner, S.; Dörner, S.; Fayt, C.; Fries, U.; García-Nieto, D.; et al. Is a scaling factor required to obtain closure between measured and modelled atmospheric $\mathrm{O}_{4}$ absorptions? An assessment of uncertainties of measurements and radiative transfer simulations for 2 selected days during the MAD-CAT campaign. Atmos. Meas. Tech. 2019, 12, 2745-2817. [CrossRef]

(C) 2020 by the authors. Licensee MDPI, Basel, Switzerland. This article is an open access article distributed under the terms and conditions of the Creative Commons Attribution (CC BY) license (http://creativecommons.org/licenses/by/4.0/). 